\title{
Health Risk Assessment of Potentially Toxic Metals in Differently Packaged Soft Drinks and Malt Products Commonly Consumed in Nigeria
}

\author{
John Adekunle Oyedele Oyekunle ${ }^{1, ~ *, ~ S o l o m o n ~ S u n d a y ~ D u r o d o l a ~}{ }^{1, ~ *}$, Fehintola Folakemi Oguntade ${ }^{1}$, \\ Abolanle Saheed Adekunle ${ }^{1}$, Wasiu Oladotun Makinde ${ }^{2}$, Saheed Eluwale Elugoke ${ }^{1}$, \\ Adeniyi Jide Oyinloye ${ }^{1}$, Aderemi Okunola Ogunfowokan ${ }^{1}$ \\ ${ }^{1}$ Department of Chemistry, Obafemi Awolowo University, Ile-Ife, Nigeria \\ ${ }^{2}$ Centre for Energy Research and Development, Obafemi Awolowo University, Ile-Ife, Nigeria
}

Email address:

oyekunle@oauife.edu.ng (J. A. O. Oyekunle),solomonsun77@gmail.com (S. S. Durodola)

${ }^{*}$ Corresponding author

\section{To cite this article:}

John Adekunle Oyedele Oyekunle, Solomon Sunday Durodola, Fehintola Folakemi Oguntade, Abolanle Saheed Adekunle, Wasiu Oladotun Makinde, Saheed Eluwale Elugoke, Adeniyi Jide Oyinloye, Aderemi Okunola Ogunfowokan. Health Risk Assessment of Potentially Toxic Metals in Differently Packaged Soft Drinks and Malt Products Commonly Consumed in Nigeria. Colloid and Surface Science.

Vol. 4, No. 2, 2019, pp. 17-23. doi: 10.11648/j.css.20190402.11

Received: December 3, 2019; Accepted: December 18, 2019; Published: December 24, 2019

\begin{abstract}
Some commonly consumed differently packaged soft drinks were investigated for their levels of $\mathrm{As}, \mathrm{Cd}, \mathrm{Co}, \mathrm{Cu}$, $\mathrm{Mn}, \mathrm{Pb}$ and $\mathrm{Zn}$. This was done in order to evaluate the effect of container materials on the levels of potentially toxic metals in the drinks and the health related short and long-term implications of regular consumption of these products. Batches of differently packaged soft drinks (in glass bottles, cans and plastic bottles) in Nigeria were purchased from wholesale stores in Ile-Ife, Nigeria. Atomic Absorption Spectrophotometer (AAS) was used to quantify the total amount of metals in the acid digested samples. The study revealed that most of the analyzed potentially toxic metals were at concentrations above the recommended WHO and USEPA permissible limits. The effect of packaging materials on the concentration of some of the analyzed metals in the soft drinks was significant at 95\% confident level. From the results of this study, it could be concluded that caution should be exercised regarding regular and consistent consumption of these soft drinks as such habit might constitute a significant source of exposure to potentially toxic metals.
\end{abstract}

Keywords: Toxic Metals, Soft Drinks, Health Risks, Consumption, Ile-Ife, Nigeria

\section{Introduction}

Several synthetic beverages are consumed in Nigeria irrespective of age, sex, religion and socioeconomic status. Soft drinks are highly valued, tasty drinks and usually have exceptional nutritional qualities. They can, however, be a potential source of toxic elements, some of which have an accumulative effect or cause nutritional problems because of low concentrations of essential elements, justifying the regulation of mineral composition in drinks [1]. In human beings, heavy metals have been reported to affect cellular organelles and components such as cell membrane, mitochondrial and some enzymes involved in metabolism, detoxification, and damage repair [2, 3]. Several studies from the laboratory have demonstrated that reactive oxygen species production and oxidative stress play an important role in the toxicity and carcinogenicity of metals such as As, Cd, $\mathrm{Cr}, \mathrm{Pb}$ and $\mathrm{Hg}$ [4]. Due to their high degree of toxicity, these five elements are among the most important metals of great importance for public health.

These metals are all systemic toxicants that are known to induce multiple organ damage, even at lower levels of exposure; each of them is known to have unique features and physicochemical properties that confer on it its specific toxicological mechanisms of action [4]. Differently packaged soft drinks are being consumed largely by children, adolescents and adults due to their appealing flavour and 
ability to quench thirst [5]. These features are defined by the constituents present in the drinks which may include vitamins, phosphates, acids and antioxidants which are of nutritional and health benefits to the body [6]. However, due to the increased level of consumption and demand of soft drinks, maintaining the standard quality within the process of production especially during sterilization and purification may be difficult to achieve. In addition, the presence of some heavy metals in soft drinks could be due to environmental contamination of water, fruits, and other ingredients utilized during production.

The aim of this study was to determine the consumption safety status of some of the available commercial differently packaged soft drinks in the Nigerian markets with respect to their levels of potentially toxic metal content.

\section{Methodology}

\subsection{Sterilization of Apparatus}

The apparatus used, such as beakers $(100 \mathrm{~mL})$, watch glass, glass rod, measuring cylinder, sample bottles with cover and a volumetric flask $(25 \mathrm{~mL})$, were thoroughly washed with liquid detergent followed by thorough rinsing with tap water until no foams were seen. Distilled water was finally used to rinse in triplicates.

\subsection{Sampling of Soft Drinks}

Batches of differently packaged soft drinks (in glass bottles, cans and plastic bottles) commonly consumed in Nigeria were purchased from wholesale stores and outlets in Ile-Ife, Nigeria. A total of 18 sets of soft drinks were thus collected. These were transported to the laboratory and subjected to immediate analysis.

\subsection{Determination of pH of Soft Drinks}

To refresh the sensitivity of the $\mathrm{pH}$ meter used, it was immersed overnight in $1.0 \mathrm{M} \mathrm{HCl}$ acid solution and rinsed three times with distilled water before used to measure the $\mathrm{pH}$ values of the soft drinks. About $20 \mathrm{~mL}$ of the freshly opened soft drink was poured into a prewashed $100 \mathrm{~mL}$ beaker that was freshly rinsed with distilled water and the $\mathrm{pH}$ meter was immersed into it. A triplicate analysis was carried out on each batch of the soft drinks.

\subsection{Digestion of the Samples}

Twenty millilitre $(20 \mathrm{~mL})$ of each of the samples (soft drinks) was put into a Teflon beaker, $10 \mathrm{~mL}$ of $\mathrm{HNO}_{3}$ was added and was placed on a thermostated hotplate in a fume cupboard and heated between $120-150^{\circ} \mathrm{C}$ to decompose organic material and convert the metals present into soluble forms. During the digestion process, the beaker was covered with a watch glass while the content of the beaker was replenished with $\mathrm{HNO}_{3}$ from time to time to avoid total dryness. After about 40 minutes, the mixture was then brought down to simmer for about 10 minutes before $2 \mathrm{~mL}$ of
$\mathrm{HClO}_{4}$ was added and digested further until a clear solution was obtained. After cooling, the content of the beaker was quantitatively transferred into a $25 \mathrm{~mL}$ volumetric flask and the volume was made to the mark with doubly distilled water. For each digestion, a blank was also prepared.

\subsection{Instrumentation}

Profiling of the elements of interest in the samples was done using the Atomic Absorption Spectroscopy model PG 990 AAS, available at the Centre for Energy Research and Development, Obafemi Awolowo University, Ile-Ife. Actual concentration of a metal, $[\mathrm{M}]_{\mathrm{a}}$, in the samples was evaluated using the relationship:

$$
[\mathrm{M}]_{\mathrm{a}}=[\mathrm{M}]_{\mathrm{i}} \mathrm{x} \text { d.f. }
$$

where $[\mathrm{M}]_{\mathrm{a}}=$ actual metal concentration; $[\mathrm{M}]_{\mathrm{i}}=$ the instrumental value of the metal; and d.f. = dilution factor.

\subsection{Quality Control and Reliability Measures}

The accuracy of the analytical procedures used in this analysis has been checked in terms of blank determination, quality control, percentage recovery $(\% \mathrm{R})$ and linearity of calibration $\left(r^{2}\right)$. Blank determination is a procedure which follows all steps of analysis but precludes the sample being analysed. It is used for the detection and compensation of systematic errors. Recovery analysis was performed by spiking a measured quantity of the sample with a known concentration of solutions of $\mathrm{As}, \mathrm{Cd}, \mathrm{Cu}$, $\mathrm{Mn}, \mathrm{Pb}$ and $\mathrm{Zn}$, while an equivalent sample quantity was left unspiked. The two samples were carried through digestion process and percentage recoveries $(\% \mathrm{R})$ were evaluated from:

$$
\% \mathrm{R}=\frac{\mathrm{A}-\mathrm{B}}{\mathrm{C}}
$$

where $\mathrm{A}=$ Concentration of metals in the spiked sample; $\mathrm{B}=$ Concentration of metals in unspiked sample; and $\mathrm{C}=$ the amount of metal in the solution used for spiking.

\section{Results and Discussion}

\subsection{Validation of Analytical Procedures Used}

Results of percentage recovery $(\% \mathrm{R})$ and linearity of calibration $\left(\mathrm{r}^{2}\right)$ with their values are listed in Table 1 . The recovery values of potentially toxic metals in the samples ranging from $87.6 \%$ in $\mathrm{Mn}$ to $98.2 \%$ in $\mathrm{Zn}$. The $\% \mathrm{R}$ values obtained were within the $70-100 \%$ range stipulated by the EU Guidelines as the acceptable \% R range for evaluating accuracy and precision of a method [7]. For AAS used, high linearity with $\mathrm{r}^{2}$ values ranging from 0.9878 for $\mathrm{Pb}$ to 0.9991 for $\mathrm{Mn}$ was shown in the standard calibration curves obtained. These values were satisfactorily reliable to give precise and accurate metal concentration determinations in the samples. 
Table 1. Calibration Parameters of AAS and \%Recovery of Potentially Toxic Metals.

\begin{tabular}{lllll}
\hline Metal & Current $(\mathbf{m A})$ & Wavelength $(\mathbf{n m})$ & Calibration curve $\left(\mathbf{r}^{\mathbf{2}}\right)$ & Percentage recovery $(\mathbf{\%} \mathbf{R})$ \\
\hline $\mathrm{As}$ & 7 & 210.1 & 0.9936 & 96.9 \\
$\mathrm{Cd}$ & 8 & 228.6 & 0.9979 & 92.3 \\
$\mathrm{Co}$ & 7 & 211.5 & 0.9947 & 95.4 \\
$\mathrm{Cu}$ & 6 & 325.1 & 0.9968 & 96.5 \\
$\mathrm{Mn}$ & 10 & 280.0 & 0.9991 & 87.6 \\
$\mathrm{~Pb}$ & 10 & 282.9 & 0.9878 & 95.9 \\
$\mathrm{Zn}$ & 8 & 214.2 & 0.9956 & 98.2 \\
\hline
\end{tabular}

\subsection{Levels of Heavy Metals in Soft Drinks Samples}

Levels of $\mathrm{As}, \mathrm{Cd}, \mathrm{Cu}, \mathrm{Co}, \mathrm{Mn}, \mathrm{Pb}$ and $\mathrm{Zn}$ recorded in the soft drinks analysed are listed in Table 2. The results obtained showed that most of the soft drink samples investigated contained the metals at levels above the [8] and [9] permissible levels irrespective of the container used to package them. However, the total concentrations of heavy metals found in the soft drinks packaged in plastic materials were significantly higher $(\mathrm{P} \leq 0.05)$ than those packaged in glass bottles. This could be caused by the leaching of metals from the plastic materials into the soft drinks as a result of flexibility of plastic to heat and stress during handling and storage. The leaching process could be enhanced because of the $\mathrm{pH}$ of samples, which was in the range of $2.1-2.9$ for soft drinks packaged in plastic materials (CCP, CFP, CSP, PCP, TMP, SUP). It is a common knowledge that when a liquid is in contact with a given matrix, the lower the $\mathrm{pH}$ the higher the ability of the liquid media to leach metals from the matrix harbouring the metals. For soft drinks packaged in glass bottles, two reasons could be adduced for their generally lower total metal content. The metals were probably not readily accessible to the liquids as they were held firmly within the glass crystals of the bottles. Also, the $\mathrm{pH}$ values of the soft drinks in glass bottles (CCB, CFB, $\mathrm{CSB}, \mathrm{PCB}, \mathrm{TMB}, \mathrm{SUB}, \mathrm{AMB}, \mathrm{MGB}, \mathrm{MAB}$ ), ranging from $2.0-3.1$, were generally slightly higher than those of plastic bottles. Thus, soft drinks in glass bottles possessed correspondingly lower leaching ability.

The concentration of arsenic in all the analyzed soft drinks samples ranged between 0.16 and $0.53 \mathrm{mg} / \mathrm{L}$. These values were above the safe limit of $0.01 \mathrm{mg} / \mathrm{L}$ recommended by [9]. High levels of arsenic above permissible limit were reported earlier in about $46 \%$ beverages from Nigerian market [10]. Exposure to high doses of arsenic is toxic and can cause various health effects, such as irritation of the stomach and intestines, nerve injury and stomach aches $[11,12]$.

The values of cadmium in the samples with a range of 0.27 to $1.28 \mathrm{mg} / \mathrm{L}$ were found to be above the [9] recommended safe limit of $0.003 \mathrm{mg} / \mathrm{L}$. Cadmium is one of the metals considered non-essential and bio toxic even at very low concentrations $[13,14]$ reported the respective $\mathrm{Cd}$ ranges from 0.003 to $0.081 \mathrm{mg} / \mathrm{L}$ and 0.006 to $0.071 \mathrm{mg} / \mathrm{L}$ in canned and non-canned drinks. Cadmium has been found to cause nausea, vomiting, diarrhea, and so on [15]. The main organ damaged following long-term exposure is the kidney, the primary site of action being the proximal tubules being [16].
The level of cobalt detected in the soft drinks samples were in the range 0.44 to $0.97 \mathrm{mg} / \mathrm{L}$. Thus, the values exceeded $0.05 \mathrm{mg} / \mathrm{L}$ maximum permissible level [9]. At some regulated levels, it has also been used as a treatment for anemia, because it stimulates red blood cells production [17]. Cobalt exposure, at both chronic and elevated levels above a normal dietary intake, may lead to nausea, vomiting, diarrhea, coughing, wheezing, dyspnoea, organ toxicity, and cardiomyopathy, or may cause allergic contact dermatitis, blood cells damage, liver injury, and allergic dermatitis [18, 19].

Copper ion is one of the many metal ions that are regarded as essential because they are required for vital body functions. However, too much or little of copper ingestion has its own unique health implications. The safe value of copper in food stuff as reported by [20] is $73.3 \mathrm{ppm}$. The level of copper detected in the soft drinks samples were in the range 0.84 to $2.44 \mathrm{mg} / \mathrm{L}$. [12] reported maximum concentration of $3.25 \mathrm{mg} / \mathrm{L}$ for copper in non-alcoholic drinks. Some of the manifestations of copper deficiency are fatigue and weakness because it is essential for absorbing iron from the gut and cells use copper to generate adenosine triphosphate (ATP), diminished level of healthy immune system, experiencing osteoporosis (development of weak and brittle bones, which increases as one ages), memory loss (Alzheimer's disease) and inability to learn with ease, difficulty in walking properly, excessive sensitivity to colds, improper functioning of the thyroid hormones, having pale skins and premature gray hair growth, and loss of vision as a result of long-term copper deficiency, among others [21, 22]. The soft drinks included in the present study did not contain enough copper to meet the body requirements

Manganese plays an essential role in living things including oxidative phosphorylation, metabolism of fatty acid and cholesterol [23, 24]. However, higher concentrations above maximum contaminant level have been reported in non-alcoholic canned drinks consumed in Nigeria by [25]. The level of manganese detected in this present study ranges between $0.25-0.66 \mathrm{mg} / \mathrm{L}$. These values are above the safe limit of $0.10 \mathrm{mg} / \mathrm{L}$ recommended by [9], slow movement, tremors among others can result in prolong exposure to excess manganese. [26].

Lead is well known to cause toxicity and poisoning in individuals exposed to it, which can lead to various disease conditions such as high blood pressure, anemia [27, 28]. The concentration of lead detected in the soft drinks samples were in the range 0.21 to $0.63 \mathrm{mg} / \mathrm{L}$. This level exceeded the [9] 
set safe limits of $0.01 \mathrm{mg} / \mathrm{L}$. In non-alcoholic drinks, some high concentrations of lead up to $0.447 \mathrm{mg} / \mathrm{L}$ were reported by [12], while [29] reported low concentrations of lead of about $0.0022 \mathrm{mg} / \mathrm{L}$. This high level of lead detected in this present study is of great concern as this could lead to lead toxicity and some diseases associated with high concentration of lead in the body.

Zinc is an essential trace element found in virtually all foods and portable water in form of salts or organic complexes. It plays important functions in the human body, such as wound healing, proper thyroid functioning, maintenance of good vision [30, 22, 12]. Nevertheless, low levels or excess of zinc in the body are associated with the incidence of development of prostate enlargement and human cancer [31]. The concentration of zinc detected in the soft drinks samples were in the range 2.19 to $5.89 \mathrm{mg} / \mathrm{L}$. These values are below the safe limit of $5.00 \mathrm{mg} / \mathrm{L}$ recommended by [9], this level of zinc could not be considered as a treat to the health of the consumers.

Table 2. Levels $(\mathrm{mg} / \mathrm{L})$ of metals in soft drinks.

\begin{tabular}{|c|c|c|c|c|c|c|c|c|c|}
\hline Soft Drink Code & As & Cd & Co & $\mathrm{Cu}$ & Mn & $\mathbf{P b}$ & Zn & Total & $\mathbf{p H}$ \\
\hline $\mathrm{CCB}$ & $0.16 \pm 0.01$ & $0.27 \pm 0.01$ & $0.44 \pm 0.02$ & $0.84 \pm 0.04$ & $0.26 \pm 0.06$ & $0.33 \pm 0.03$ & $2.24 \pm 0.01$ & 4.54 & 2.2 \\
\hline $\mathrm{CCP}$ & $0.28 \pm 0.04$ & $0.49 \pm 0.03$ & $0.75 \pm 0.03$ & $1.37 \pm 0.04$ & $0.41 \pm 0.06$ & $0.40 \pm 0.02$ & $4.56 \pm 0.11$ & 8.26 & 2.1 \\
\hline CFB & $0.28 \pm 0.01$ & $0.33 \pm 0.01$ & $0.57 \pm 0.02$ & $0.10 \pm 0.04$ & $0.37 \pm 0.06$ & $0.28 \pm 0.03$ & $5.89 \pm 0.01$ & 7.82 & 2.5 \\
\hline CFP & $0.47 \pm 0.03$ & $0.49 \pm 0.06$ & $0.88 \pm 0.02$ & $1.29 \pm 0.14$ & $0.50 \pm 0.06$ & $0.44 \pm 0.05$ & $4.31 \pm 0.10$ & 8.38 & 2.5 \\
\hline CSB & $0.26 \pm 0.01$ & $0.33 \pm 0.01$ & $0.57 \pm 0.07$ & $1.01 \pm 0.04$ & $0.33 \pm 0.06$ & $0.28 \pm 0.02$ & $2.19 \pm 0.12$ & 4.97 & 3.1 \\
\hline CSP & $0.41 \pm 0.11$ & $0.47 \pm 0.13$ & $0.81 \pm 0.08$ & $1.33 \pm 0.06$ & $0.59 \pm 0.06$ & $0.44 \pm 0.06$ & $4.59 \pm 0.15$ & 8.64 & 2.9 \\
\hline PCB & $0.33 \pm 0.12$ & $0.74 \pm 0.22$ & $0.66 \pm 0.04$ & $1.62 \pm 0.22$ & $0.31 \pm 0.01$ & $0.28 \pm 0.01$ & $2.98 \pm 0.31$ & 6.92 & 2.0 \\
\hline TMB & $0.33 \pm 0.02$ & $0.83 \pm 0.12$ & $0.59 \pm 0.06$ & $1.49 \pm 0.32$ & $0.38 \pm 0.03$ & $0.47 \pm 0.05$ & $2.87 \pm 0.12$ & 6.96 & 2.1 \\
\hline TMP & $0.47 \pm 0.02$ & $1.28 \pm 0.07$ & $0.97 \pm 0.07$ & $2.35 \pm 0.52$ & $0.66 \pm 0.07$ & $0.44 \pm 0.03$ & $4.34 \pm 0.32$ & 10.51 & 2.2 \\
\hline SUB & $0.33 \pm 0.04$ & $0.83 \pm 0.05$ & $0.63 \pm 0.03$ & $1.68 \pm 0.45$ & $0.37 \pm 0.05$ & $0.38 \pm 0.06$ & $3.00 \pm 0.22$ & 7.22 & 3.0 \\
\hline SUP & $0.53 \pm 0.03$ & $1.19 \pm 0.13$ & $0.90 \pm 0.05$ & $2.44 \pm 0.21$ & $0.66 \pm 0.04$ & $0.31 \pm 0.03$ & $4.09 \pm 0.23$ & 10.12 & 3.2 \\
\hline AMB & $0.23 \pm 0.11$ & $0.62 \pm 0.01$ & $0.54 \pm 0.03$ & $1.40 \pm 0.15$ & $0.27 \pm 0.02$ & $0.43 \pm 0.09$ & $2.68 \pm 0.19$ & 6.17 & 4.2 \\
\hline AMC & $0.21 \pm 0.03$ & $0.62 \pm 0.03$ & $0.56 \pm 0.06$ & $1.42 \pm 0.13$ & $0.25 \pm 0.03$ & $0.45 \pm 0.11$ & $2.81 \pm 0.29$ & 6.32 & 4.1 \\
\hline MGB & $0.29 \pm 0.02$ & $0.58 \pm 0.05$ & $0.62 \pm 0.03$ & $1.57 \pm 0.16$ & $0.41 \pm 0.07$ & $0.33 \pm 0.01$ & $2.91 \pm 0.18$ & 6.71 & 4.3 \\
\hline MAC & $0.25 \pm 0.02$ & $0.31 \pm 0.03$ & $0.62 \pm 0.12$ & $1.38 \pm 0.14$ & $0.45 \pm 0.05$ & $0.21 \pm 0.02$ & $2.52 \pm 0.16$ & 5.74 & 4.1 \\
\hline USEPA & 0.01 & 0.005 & NA & 1.30 & 0.05 & 0.015 & 5.00 & & \\
\hline$*_{\mathrm{WHO}}$ & 0.01 & 0.003 & 0.05 & 2.00 & 0.10 & 0.01 & 5.00 & & \\
\hline
\end{tabular}

* Maximum permissible limit $(\mathrm{mg} / \mathrm{L})$ of potentially toxic metals in drinking water (WHO and USEPA, 2011). NA = Not available

\subsection{Estimated Daily Intake (EDI) of Heavy Metal}

Estimated Daily Intake (EDI) of the metals depended on both the metal concentration in the soft drinks and the amount of consumption of the soft drinks. The Estimated Daily Intake for adult was determined by the following equation:

$$
\mathrm{EDI}=\frac{\mathrm{C}_{\text {metal }} \mathrm{X} \mathrm{C}_{\text {factor }} \mathrm{XD}_{\text {food intake }}}{\mathrm{B}_{\mathrm{w}}}
$$

where $\mathrm{C}_{\text {metal }}$ represents the metal concentration in soft drinks, $\mathrm{C}_{\text {factor }}$ represents conversion factor $(0.085), \mathrm{D}_{\text {food intake }}$ represents daily intake of soft drinks, and $\mathrm{B}_{\mathrm{w}}$ is average body weight, respectively.

The conversion factor $(0.085)$ was used to convert fresh weight into dry weight [32]. The average daily intake of soft drinks was considered to be $30 \mathrm{cL}$ per person per day [33]. $60 \mathrm{~kg}$ was considered as the average body weight. The values for the estimated daily intake of the analyzed soft drinks are shown in Table 3.

Table 3. Calculated EDI in the Soft drinks $\left(x 10^{-5} \mathrm{mg} / \mathrm{L}\right)$.

\begin{tabular}{llllllll}
\hline $\begin{array}{l}\text { Sample } \\
\text { Code }\end{array}$ & As & Cd & Co & Cu & Mn & Pb & Zn \\
\hline CCB & 6.8 & 11.0 & 19.0 & 36.0 & 11.0 & 14.0 & 95.2 \\
CCP & 11.9 & 21.0 & 32.0 & 58.0 & 17.0 & 17.0 & 193.8 \\
\hline
\end{tabular}

\begin{tabular}{llllllll}
\hline $\begin{array}{l}\text { Sample } \\
\text { Code }\end{array}$ & As & Cd & Co & Cu & Mn & Pb & Zn \\
\hline CFB & 11.9 & 14.0 & 24.0 & 4.3 & 16.0 & 12.0 & 250.3 \\
CFP & 20.0 & 21.0 & 37.0 & 55.0 & 21.0 & 19.0 & 183.2 \\
CSB & 11.1 & 14.0 & 24.0 & 43.0 & 14.0 & 12.0 & 93.1 \\
CSP & 17.4 & 20.0 & 34.0 & 57.0 & 25.0 & 19.0 & 195.1 \\
PCB & 1.4 & 31.0 & 28.0 & 69.0 & 13.0 & 12.0 & 126.7 \\
PCP & 20.0 & 44.0 & 39.0 & 101.0 & 16.0 & 27.0 & 186.2 \\
TMB & 14.0 & 35.0 & 25.0 & 63.0 & 16.0 & 20.0 & 122.0 \\
TMP & 20.0 & 54.0 & 41.0 & 100.0 & 28.0 & 19.0 & 184.5 \\
SUB & 14.0 & 35.0 & 27.0 & 71.0 & 16.0 & 16.0 & 127.5 \\
SUP & 22.5 & 51.0 & 38.0 & 104.0 & 28.0 & 13.0 & 173.8 \\
AMB & 9.8 & 26.0 & 23.0 & 60.0 & 11.0 & 18.0 & 113.9 \\
AMC & 8.9 & 26.0 & 24.0 & 60.0 & 11.0 & 19.0 & 119.4 \\
MGB & 12.3 & 25.0 & 26.0 & 67.0 & 17.0 & 14.0 & 123.7 \\
MGC & 11.9 & 26.0 & 24.0 & 55.0 & 11.0 & 17.0 & 105.4 \\
MAB & 10.6 & 12.0 & 26.0 & 61.0 & 13.0 & 9.8 & 119.4 \\
MAC & 10.6 & 13.0 & 26.0 & 59.0 & 19.0 & 8.9 & 107.1 \\
\hline
\end{tabular}

\subsection{The Health Risk Index}

The Health Risk Index (HRI) for the consumption of contaminated soft drink was evaluated from the relationship:

$$
\mathrm{HRI}=\frac{\mathrm{EDI}}{\mathrm{TDI}}
$$

Where, EDI is the estimated daily intake of metals and TDI is the tolerable daily intake for each metal.

When the HRI $<1$, it means that the exposed population is 
assumed to be safe. Oral reference dose for $\mathrm{As}, \mathrm{Cd}, \mathrm{Co}, \mathrm{Cu}$, $\mathrm{Mn}, \mathrm{Pb}$, and $\mathrm{Zn}$ were $3.00 \times 10^{-4}, 5.00 \times 10^{-4}, 3.00 \times 10^{-4}$, $4.00 \times 10^{-2}, 1.40 \times 10^{-1}, 3.5 \times 10^{-3}$ and $3.0 \times 10^{-1}[8,34,35$,
$36,37,38]$. The values obtained for the health risk index for the soft drinks analyzed are presented in Table 4.

Table 4. HRI of the Soft drinks.

\begin{tabular}{|c|c|c|c|c|c|c|c|}
\hline Sample Code & As & Cd & Co & $\mathrm{Cu}$ & Mn & $\mathbf{P b}$ & Zn \\
\hline $\mathrm{CCB}$ & 0.267 & 0.230 & 0.623 & 0.009 & 0.001 & 0.040 & 0.003 \\
\hline $\mathrm{CCP}$ & 0.397 & 0.417 & 1.063 & 0.015 & 0.001 & 0.049 & 0.007 \\
\hline CFB & 0.397 & 0.281 & 0.808 & 0.001 & 0.001 & 0.034 & 0.008 \\
\hline CFP & 0.666 & 0.417 & 1.247 & 0.014 & 0.002 & 0.053 & 0.006 \\
\hline CSB & 0.368 & 0.281 & 0.808 & 0.011 & 0.001 & 0.034 & 0.003 \\
\hline CSP & 0.581 & 0.400 & 1.148 & 0.014 & 0.002 & 0.053 & 0.007 \\
\hline PCB & 0.468 & 0.629 & 0.935 & 0.017 & 0.001 & 0.034 & 0.004 \\
\hline TMB & 0.468 & 0.706 & 0.836 & 0.016 & 0.001 & 0.057 & 0.004 \\
\hline TMP & 0.666 & 1.088 & 1.374 & 0.025 & 0.002 & 0.053 & 0.006 \\
\hline SUB & 0.468 & 0.706 & 0.893 & 0.018 & 0.001 & 0.046 & 0.004 \\
\hline SUP & 0.751 & 1.012 & 1.275 & 0.026 & 0.002 & 0.038 & 0.006 \\
\hline AMB & 0.326 & 0.527 & 0.765 & 0.015 & 0.001 & 0.052 & 0.004 \\
\hline $\mathrm{AMC}$ & 0.298 & 0.527 & 0.793 & 0.015 & 0.001 & 0.055 & 0.004 \\
\hline MGB & 0.411 & 0.493 & 0.878 & 0.017 & 0.001 & 0.040 & 0.004 \\
\hline MGC & 0.397 & 0.510 & 0.793 & 0.014 & 0.001 & 0.047 & 0.004 \\
\hline MAC & 0.354 & 0.264 & 0.878 & 0.015 & 0.001 & 0.026 & 0.004 \\
\hline
\end{tabular}

\subsection{Correlation Matrix of the Analyzed Metals in the Soft Drinks Samples}

Based on the data in Table 5 there are strong correlations between $\mathrm{Cd}$ and $\mathrm{As}, \mathrm{Co}$ and $\mathrm{Cd}, \mathrm{Co}$ and $\mathrm{As}, \mathrm{Co}$ and $\mathrm{Cd}, \mathrm{Cu}$ and $\mathrm{As}, \mathrm{Cu}$ and $\mathrm{Cd}, \mathrm{Cu}$ and $\mathrm{Co}, \mathrm{Mn}$ and $\mathrm{As}, \mathrm{Mn}$ and $\mathrm{Cd}, \mathrm{Mn}$ and $\mathrm{Co}, \mathrm{Mn}$ and $\mathrm{Cu}, \mathrm{Pb}$ and $\mathrm{Cd}, \mathrm{Zn}$ and $\mathrm{As}, \mathrm{Zn}$ and $\mathrm{Co}, \mathrm{Zn}$ and $\mathrm{Mn}$. This means that the metals probably have the same origin.

The single factor analysis of variance was carried out on the soft drinks samples using Microsoft Excel computer software package. If $\mathrm{F}_{\text {cal }}>\mathrm{F}$ critical, the null hypothesis is rejected. However, this is not the case as $0.311<1.718$ as shown in Table 5. Therefore, we accept the null hypothesis. Thus, the means of the eighteen population are not all equal.

Table 5. Correlation matrix of the analyzed metals in the soft drinks samples.

\begin{tabular}{llllllll}
\hline & As & Cd & Co & Cu & Mn & Pb & Zn \\
\hline $\mathrm{As}$ & 1 & & & & & & \\
$\mathrm{Cd}$ & 0.719 & 1 & & & & & \\
$\mathrm{Co}$ & 0.930 & 0.655 & 1 & & & & \\
$\mathrm{Cu}$ & 0.660 & 0.842 & 0.685 & 1 & & & \\
$\mathrm{Mn}$ & 0.803 & 0.506 & 0.824 & 0.488 & 1 & & \\
$\mathrm{~Pb}$ & 0.412 & 0.506 & 0.435 & 0.411 & 0.087 & 1 & \\
$\mathrm{Zn}$ & 0.571 & 0.232 & 0.620 & -0.006 & 0.557 & 0.277 & 1 \\
\hline
\end{tabular}

$\mathrm{n}=18, \alpha=0.05, \mathrm{r} \geq 0.455$ at $95 \%$ confidence interval

\subsection{T-test Analysis}

The T-test analysis was carried out to test whether there is a significant difference among the values obtained for the concentration of the heavy metals in soft drinks packaged in bottle, plastic and can according to the equation:

$$
\mathrm{t}=\frac{\overline{\mathrm{x}_{1}}-\overline{\mathrm{x}_{2}}}{\mathrm{~s}_{\text {pooled }}}
$$

where $\overline{X_{1}}=$ mean of concentration of the soft drinks in a particular container, $\overline{X_{2}}=$ mean of concentration of the soft drinks in another container,

$$
S_{\text {pooled }}=\sqrt{\left(\frac{S_{1}}{\sqrt{\mathrm{N}_{1}}}\right)^{2}+\left(\frac{\mathrm{S}_{2}}{\sqrt{\mathrm{N}_{2}}}\right)^{2}},
$$

$\mathrm{S}_{1}=$ standard deviation of concentration of the soft drinks in a particular container, $S_{2}=$ standard deviation of concentration of the soft drinks in another container, $\mathrm{N}_{1}=$ number of the soft drinks in a particular container, $\mathrm{N}_{2}=$ number of concentration of the soft drinks in another container.

There is a significant difference if the $t_{\text {calculated }}$ is greater than the $t_{\text {critical, }}$ and vice-versa. The result of the T-test analysis presented in Table 6 shows that there was a significant difference among the mean value of the concentration of the analyzed metals in the soft drinks packaged in bottle and plastic, plastic and can, but there was no significant difference in mean values of the concentration of the analyzed metals in the soft drinks packaged in bottle and can.

\begin{tabular}{|c|c|c|c|c|c|c|}
\hline \multirow{2}{*}{ Element } & \multicolumn{2}{|c|}{ Bottle and Plastic } & \multicolumn{2}{|c|}{ Bottle and Can } & \multicolumn{2}{|c|}{ Plastic and Can } \\
\hline & T-test value & Remark & T-test value & Remark & T-test value & Remark \\
\hline As & 4.595 & $\mathrm{SD}$ & 0.118 & NSD & 0.162 & NSD \\
\hline $\mathrm{Cd}$ & 1.813 & NSD & 0.275 & NSD & 7.033 & $\mathrm{SD}$ \\
\hline
\end{tabular}

Table 6. T-test comparing analyzed metals in soft drinks packaged in bottle, plastic and can. 


\begin{tabular}{|c|c|c|c|c|c|c|}
\hline \multirow{2}{*}{ Element } & \multicolumn{2}{|c|}{ Bottle and Plastic } & \multicolumn{2}{|c|}{ Bottle and Can } & \multicolumn{2}{|c|}{ Plastic and Can } \\
\hline & T-test value & Remark & T-test value & Remark & T-test value & Remark \\
\hline $\mathrm{Co}$ & 8.286 & $\mathrm{SD}$ & 0.000 & NSD & 8.878 & $\mathrm{SD}$ \\
\hline $\mathrm{Cu}$ & 1.127 & NSD & 0.256 & NSD & 0.714 & NSD \\
\hline $\mathrm{Mn}$ & 4.167 & SD & 0.182 & NSD & 0.306 & NSD \\
\hline $\mathrm{Pb}$ & 2.391 & SD & 0.313 & NSD & 1.277 & NSD \\
\hline $\mathrm{Zn}$ & 3.771 & SD & 1.289 & NSD & 16.182 & $\mathrm{SD}$ \\
\hline
\end{tabular}

$\mathrm{SD}=$ Significant difference. $\mathrm{NSD}=$ No significant difference

$t_{\text {critical }}=2.160,2.228$ and 2.365 for Bottle and Plastic, Bottle and Can, Plastic and Can respectively at 95\% confidence level.

\section{7. pH of Soft Drinks}

All the soft drinks were acidic with their $\mathrm{pH}$ from 2.0 to 4.3. These results were compared with WHO standard [39], which is 3 to 5 and $50 \%$ of the samples (CCB, CCP, CFB, CFP, CSP, PCB, PCP, TMB and TMP) had pH less than the standard such as shown in Table 2.

Most foods are less acidic than the usual 1.0 to $3.0 \mathrm{pH}$ in the stomach. The acidity of soft drinks alone may not cause a peptic ulcer or significantly inhibit the healing process, but its caffeine content may stimulate the secretion of stomach acid resulting in pain and discomfort for those with ulcers [40].

\section{Conclusion}

This study revealed that most of the soft drinks commonly consumed are a potential source of potentially toxic metals. Bearing in mind that these beverages were taken by infants and growing children, who are at their stage of development and growth, the amount of $\mathrm{Pb}$ found in drinks is a major concern. The result of this study showed that $\mathrm{Zn}$ and $\mathrm{Mn}$ exhibited highest levels in the soft drinks, while As and $\mathrm{Cd}$ had the lowest levels. There is the need for manufacturers to ensure that the quality of materials used for processing of the soft drinks are not compromised at any stage of manufacturing so as to reduce external addition of contaminants to the barest minimum.

\section{References}

[1] Torres, B., Tiwari, B. K., Patras, A., Cullen, P. J., Brunton, N. and Odonnell, C. P., 2011. Stability of Anthocyanins and Ascorbic Acid of High Pressure Processed Blood Orange Juice During Storage. Innovative Food Science and Emerging Technologies 12 (2), 93-97.

[2] Wang S, and Shi X., 2001. "Molecular Mechanisms of Metal Toxicity and Carcinogenesis". Mol Cell Biochem. 2001; 222: 3-9.

[3] Ayannuga, A. A., Oyekunle, J. A., Ijomone, O. M. and Ibeachusim, B. I., 2015. Cadmium and Lead Toxicity, Modulating Roles of Age and Trace Metals on Wistar Rat Cortical Cells. Environment and Pollution, 4 (3): 51-61.

[4] Tchounwou, P. B., Yedjou, C. G., Patlolla, A. K., \& Sutton, D. J., 2012. Heavy Metal Toxicity and the Environment. Molecular, Clinical and Environmental Toxicology, 133-164.

[5] Kirk - Pearson, R. S., 1991. Composition and Analysis of Foods (9th ed) Longman. p289.
[6] Pafahl G. M., Capps, O. Jr., Clauson, A., 2005. "Demand for Non-alcoholic Beverages: Evidence from the A C - Nelson. Home Scan Panel" Paper presented at the American Agricultural Economics Association annual meeting providence, Rhode Island.

[7] European Union, EU, 1999. European Union Directive 1999/74/EC. Laying downminimum standards for the protection of laying hens.

[8] USEPA IRIS (US Environmental Protection Agency), 2011. Integrated Risk Information System. Environmental Protection Agency Region I, Washington DC 20460. http://www.epa.gov/iris/.

[9] World Health Organization (WHO), 2011. Guidelines for drinking-water quality, fourth edition. Retrieved from http://whqlibdoc.who.int/publications/2011/978924154815 1 .

[10] Maduabuchi, J. M. U.; Adigba, E. O.; Nzegwu, C. N.; Oragwu, C. I.; Okonkwo, I. P.; Orisakwe, O. E., 2007. Arsenic and chromium in canned and non-canned beverages in Nigeria: A potential public health concern. Intern. J. Environ. Res. Public Health 4, 28-33.

[11] Durodola S. S, Ayinuola. O, Ore O. T, Makinde W. O., 2019. Assessment of Human Health Risk of Potential Toxic Metals in Herbal Concoction Teas Commonly Consumed in Nigeria. World Journal of Applied Chemistry. doi: 10.11648/j.wjac.20190403.12.

[12] Salako S. G., Adekoyeni O. O., Adegbite A. A. and Hammed, T. B., 20016. Determination of Metals Content of Alcohol and Non-alcoholic Canned Drinks Consumed at Idiroko Border Town Ogun State Nigeria. British Journal of Applied Science \& Technology 12 (6): 1-8.

[13] Onweremadu, E. U. and Duruigbo, C. I., 2007. Assessment of Cd concentration of crude oil polluted arable soils, Int. J. Environ. Sci. Tech., 4: 409-412.

[14] Maduabuchi J. M. U,. Nzegwu C. N, Adigba E. O Aloke R. U, Ezomıke C. N., Okocha C. E., Obi E. and Orisakwe O. E., 2006. Lead and cadmium exposures from canned and noncanned beverages in Nigeria: A public health concern". Science Total of Environment, Vol. 366, 6, pp 621-626.

[15] Magomya, A. M, Yebpella G. G and Okpaegbe U. C., 2015. An Assessment of metal contaminant levels in selected softdrinks sold in Nigeria. International Journal of Innovative Science, Engineering \& Technology, Vol. 2.

[16] Oyekunle J. A. O, Yussuf N. A, Durodola S. S, Adekunle A. S, Adenuga A. A, Ayinuola O, Ogunfowokan A. O., 2019. Determination of polycyclic aromatic hydrocarbons and potentially toxic metals in commonly consumed beef sausage roll products in Nigeria. Heliyon 5, Elsevier. doi.org/10.1016/j.heliyon.2019.e02345. 
[17] Wolfgang Jelkmann, 2012. The Disparate Roles of Cobalt in Erythropoiesis, and Doping Relevance. Open Journal of Hematology. DOI: 10.13055/ojhmt_3_1_6.121211.

[18] Agency for Toxic Substances and Disease Registry (ATSDR 1992). Toxicological Profile for Cobalt. Public Health Service, U.S. Department of Health and Human Services, Atlanta, GA.

[19] Stuckert, J. and Nedorost, S. (2008). Low-cobalt diet for dyshidrotic eczema patients, Contact Dermatitis, 59: 361-365.

[20] FAO (Food and Agricultural Organisation), 2007. The state of foods and Agriculture. Pp 4; 40 htt://www.fao.org/giews/English/cpfs/index.htm.

[21] Reeves G. P and Demas C. S., 2004. Copper Deficiency Reduces Iron Absorption and Biological Half-Life in Male Rats. The Journal of Nutrition, Vol 134, (8) 1953-1957, https://doi.org/10.1093/jn/134.8.1953.

[22] Jeremias, C. T., David, L. B., Royden, J., 2006. Severe ataxia, myelopathy and peripheral neuropathy due to acquired copper deficiency in a patient with history of gastrectomy JPEN, Journal of parenteral and Enteral Nutrition, 30: 446 - 450.

[23] Prashanth L, Kiran Kumar Kattapagari1, Ravi TejaChitturi, Baddam V. R. R, Prasad L. K., 2015. A review on role of essential trace elements in health an.d disease. Journal of Dr. NTR University of Health Sciences. Vol 4 (2) 75-85.

[24] Izah, S. C.; Chakrabarty, N.; Srivastav, A. L., 2016. A Review on Heavy Metal concentration in PotableWaterSourcesin: Human Health Effects and Mitigating Measures. Exp. Health $8,285-304304$.

[25] Maduabuchi, J. M. U.; Nzegwu, C. N.; Adigba, E. O.; Oragwu, C. I.; Agbo, F. N.; Agbata, C. A.; Ani, G. C.; Orisakwe, O. E., 2008. Iron, manganese and nickel exposure from beverages in Nigeria: A public health concern J. Heath Sci. 54, 335-338.

[26] Iweala, E. E. J., Olugbuyiro, J. A. O., Durodola, B. M., Fubara-Manuel, D. R., Okoli, A. O., 2014. Metal contamination of foods and drinks consumed in Ota, Nigeria. Res. J. Environ. Toxicol. 8, 92-97.

[27] Garba, Z. N.; Ubam, S.; Babando, A. A.; Galadima, A., 2015. Quantitative Assessment of Heavy Metals from SelectedTea Brands Marketed in Zaria, Nigeria. J. Phys. Sci., 26, 43-51.

[28] USFDA (US. Food and Drug Administration), 2015. Q3D Elemental Impurities Guidance for industry (Report), U.S Department of Health and Human Services, pp 41.

[29] Adepoju-Bello, A. A.; Oguntibeju, O. O.; Onuegbu, M. T.; Ayoola, G. A. A.; Coker, H. A. B., 2012. Analysis of selected metallic impurities in soft drinks marketed in Lagos, Nigeria. Afr. J. Biotechnol. 11: 4676-4680.
[30] Chasapis, C. T.; Loutsidou, A. C.; Spiliopoulou, C. A.; Stefanidou, M. E., 2012. Zinc and human health: An update. Arch. Toxicol., 86, 521-534.

[31] Gonzalez, A., Peters, U., Lampe, J. W., White, E., 2009. Zinc intake from supplements and diet and prostate cancer. Nutrition and cancer, 61 (2), 206-215.

[32] Jan FA, Ishaq M, Khan S, Ihsanullah I, Ahmad I, Shakirullah M. A., 2010. Comparative study of human health risks via consumption of food crops grown on wastewater irrigated soil (Peshawar) and relatively clean water irrigated soil (lower Dir). J Hazard Mater.;179, 612-21. doi: 10.1016/j.jhazmat.2010.03.047.

[33] NSW Centre for Public Health Nutrition. 2009. Soft drinks Weight status and Health: A Review. http://www.cphn.mmb.usyd.edu.au

[34] USEPA (United State Environmental Protection Agency), 2016. USEPA Regional Screening Level (RSL) Summary Table. Available at: https://www.epa.gov/risk/regionalscreening-levels-rsls-generic-tablesmay

[35] USEPA (United States Environmental Protection Agency), 2012. EPA Region III Risk-Based Concentration (RBC) Table 2008 Region III, 1650 Arch Street, Philadelphia, Pennsylvania, 19103.

[36] USEPA (United States Environmental Protection Agency), 2013. Reference dose (RfD): Description and use in health risk assessments, Background Document 1A, Integrated risk information system (IRIS); United States Environmental Protection Agency: Washington, DC, 15, http://www epa.gov/iris/rfd.htm.

[37] World Health Organization (WHO), 1993. Evaluation of Certain Food Additives and Contaminants. In: Forty-First Report of the Joint FAO/WHO Expert Committee on Food Additives, WHO, Geneva, Switzerland. (WHO Technical Series, 837).

[38] Food and Nutrition Board. Dietary Reference Intakes [DRIs]., 2004. Recommended Intakes for Individuals. National Academy of Sciences, Washington, DC, USA.

[39] World Health Organization (WHO), 2008, Guidelines for Drinking Water Quality, World Health Organization, Geneva, Switzerland.

[40] Magut H, Anthoney T. S and Terer E. K., 2013. Determination of Caffeine and $\mathrm{pH}$ Levels of Selected Carbonated Soft Drinks and Ready to Drink Juices in Eldoret, Kenya. International Journal of Innovative Research in Engineering \& Science. ISSN 2319-5665. 